\title{
PERIODICALS OF ENGINEERING AND NATURAL SCIENCES
}

ISSN 2303-4521

Vol. 2 No. 2 (2014)

Available online at: http://pen.ius.edu.ba

\section{Science and Technology Parks and University Collaborations}

\author{
Ali GURSEL \\ Duzce University, Dept. of Mechanical Engineering, Duzce \\ Turkey
}

\begin{abstract}
Science and technology parks (STP) are seen as a catalyzer for the economic and industrial development for developing countries. For future STPs, it's needed to determine from beginning to last version of them, their properties, similar and different structures, regional priorities, expectations and etc. This study will demonstrate to create a new science and technology parks, what the potential advantages and disadvantages are and what the factors should be taken account, etc. as a compiling review.

The success of the STPs close related to University collaborations. Universities are supporting the STP firms as researchers and laboratories. University based STPs have much more benefits for researches and innovations, incubation activities, start-up/spin off firms and entrepreneurship opportunities.
\end{abstract}

Keywords: Science and Technology Parks, Incubation Centers, University Research Centers.

\section{Introduction}

Science and Technology Parks (STP)have been in existence in the United States since at least the early 1950's.Silicon Valley was a pioneer in the development of STPs the world. Originally known as Stanford University Science Park and have since spread around the world, with new technology parks continually arising. Originally, the term "technology park" had a very limited definition, focusing on the real estate aspect of the park concept, in which universities typically leased real estate, office space or research facilities to businesses. Sometimes these arrangements are referred to as "industrial estates"or "firm hotels." The term, however, has evolved to include a much broader range of functions, including economic development and technology transfer.

The official definition by the International Association of Science Parks (IASP); A science park is an organization managed by specialized professionals, whose main aim is to increase the wealth of its community by promoting the culture of innovation and the competitiveness of its associated businesses and knowledge-based institutions. To enable these goals to be met, a science park stimulates and manages the flow of knowledge and technology amongst universities, R\&D institutions, companies and markets; it facilitates the creation and growth of innovation-based companies through incubation and spinoff processes; and provides other value-added services together with high quality space and facilities. IASP's definition also goes on to say that the expression "science park" may be replaced in this definition by the expressions "technology park", "technopole" or "research park".[1].

\section{Objective and Methods}

Aim of this study is to find a path way while establishing new generation STPs with demonstrating the overall STPs, their structures and expectations from them. The literatures on science and technology parks have been reviewed. 
Statistics about STPs, different approaches for development, university, institute, research centers, incubation centersand industryand/or business relations have been analyzed. And their effects on science and technology parks criticized. The main benefits of STPs on regional and economic developments, entrepreneurial and new firm creations have been demonstrated.

STPs allover the world in numbers [2]:

- The number of technoparksallover the world is over 4000. (including incubation centers)

- The second half of the eighties was the period where most technoparks were launched. (23.38\%)

- $83 \%$ are non-profit organizations. $88 \%$ has an incubation unit in its structure; $70 \%$ was established by the public investment and $73 \%$ launches out by the land rent.
- $26 \%$ of companies in technoparks are active in ICT sector; $20 \%$ is in biotechnology; $19 \%$ is in electronics; $8 \%$ is in environment technologies, $6 \%$ is in advanced materials; $5 \%$ is in chemistry; $9 \%$ is in agriculture and 7 $\%$ is in other sectors.

- $51 \%$ of technopark companies are defined as the service companies, $18 \%$ is as industrial companies and $26 \%$ is as $R \& D$ companies.

- $89 \%$ of technopark companies are SMEs. (according to the EU standards)

According to International Association of Science ParksIASP, it's seen the Science and Technology Parkselements on Fig. 1 [3].

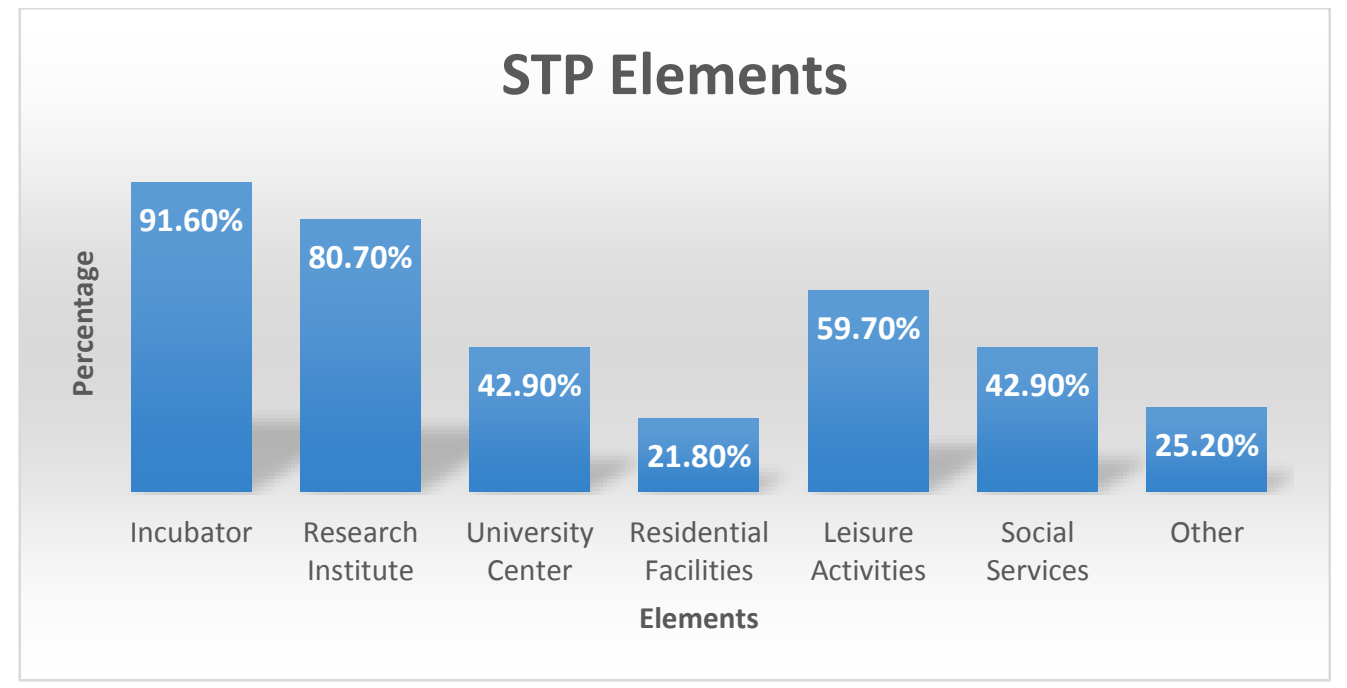

Figure 1. STP Elements

Business incubators (present in $91.6 \%$ of STPs) and research centers (present in $80.7 \%$ of STPs) are two of the most common building blocks in Parks around the world.

The STPs are divided three categories as their specializations. Specialists STPs concentrate on one or very few technology sectors. Semi-specialists are parks with a clear emphasis on one or very few technology sectors yet have companies and institutions from other sectors. Generalists do not have a clear preference in the types of technology that they work with. Regardless of the degree of specialization, all Parks have entry requisites in order to select which companies may locate in the Park[3]. Generalist STPs are more common, but for the new generation STPs, the specialist ones are more valuable.

\section{Results and Discussion}

Science and technology parks mostly related to universities or research institutes, for researchers and academician based. One of the main effective factors of potential opportunities for STP is collaborations to universities and institutes.

Science parks are often seen as, or are hoped to be, the solution to complex political and economic issues in society, for example regional industry problems [4], the under-commercialization of publicly financed research[5], a shortage of new product development, and unemployment. 
At the core of the expectation from science and technology parks is a catalyst to economic growth through its contribution to innovation and further development of high-tech firms. In the 1980s and 1990s, this belief was fuelled by the explosive growth and value creation in hightech industries such as information technology (IT), communication technologies and biotechnology [6].

Science parks serve many masters with different interests and expectations. Universities expect science parks to enable them to commercialize their researchideas and secure funding for further research. Entrepreneurs and smaller high-tech companies want high quality prestigious accommodation, a close association with the university, other similar businesses on site and the managerial services provided by the park staff [7].

\subsection{Science and technology parks and university / institute relations}

The location of science and technology parks is essential that being closer to universities or institutes. The location of STP is proximal to important customers, suppliers, researchers and other businesses/ organizations, and the NTBFs will be able to build networks that support their development. In different universities certain institutes or departments strongly relates to industry. Most accessing of academic resources relates to contacts based on recruiting university graduates or informal contacts. In different universities certain institutes or departments strongly relates to industry. The research links is possible only at the level ofthe firm involved[8]. There are two principal forms of academic-Science Park links at the level of the individual Park NTBF:

- The establishment of spin-off firms, formed by academic staff taking research out of the laboratory and onto the Science Park, starting their own commercial firms

- The occurrence of research links facilitating technology and knowledge transfers.

Research links may take many forms, from formal contracts for research to more informal contracts as well as the transfer of personnel between academia and industry [8]. The linkage between Science Park NTBFs and the university is fundamental to the concept of Science Parks. The universities and the smaller-firm sector have always played a part in economic progress. It is only in recent times that their roles were seen to overlap one another, most notably in the establishment of Science Parks. If small firms were shown to be more innovative than large firms, there would be some case for considering policies to promote their development. NTBFs are of key interest[9]:

- They are thought to embody the technologies of the future and hence provide secure employment opportunities for several generations.

- In the United States NTBFs have exhibited spectacular rates of employment growth

'Science Park Village' can be divided up on two parallel existing norms that causes building of networks. The first one were related to the academy, and the second were related to integration and acceptance how to conduct business[10]. The co-operation between firms were less than one might expect [11]. It was argued that the reason for location in a Science Park was not to establish new contacts but to preserve old ones. The lack of cooperation and networking is due to heterogeneity of the located firms[12]. Because of the different structures there is no basis for co-operation, hence there is a need for a 'critical mass' to develop.

The STSs reflect an assumption that technological innovation stems from scientific research and that STPs can provide the catalytic incubator environment for the transformation of 'pure' research into production[13]. NTBFs working with universities that are more proximity may achieve certain advantages. Proximity between firms and universities promote the natural exchange of ideas through both formal and informal networks [14]. The formal methods include licensing and cooperative alliances, while informal methods include mobility of scientists and engineers, social meetings and discussions [14-16]. Second, formal and informal exchanges provide information not only regarding formal projects, but also about on-going research among other firms and organizations. The key relationship is between the university and the NTBF and include the proximity between the firm and its university(Fig. 2)[17]. 


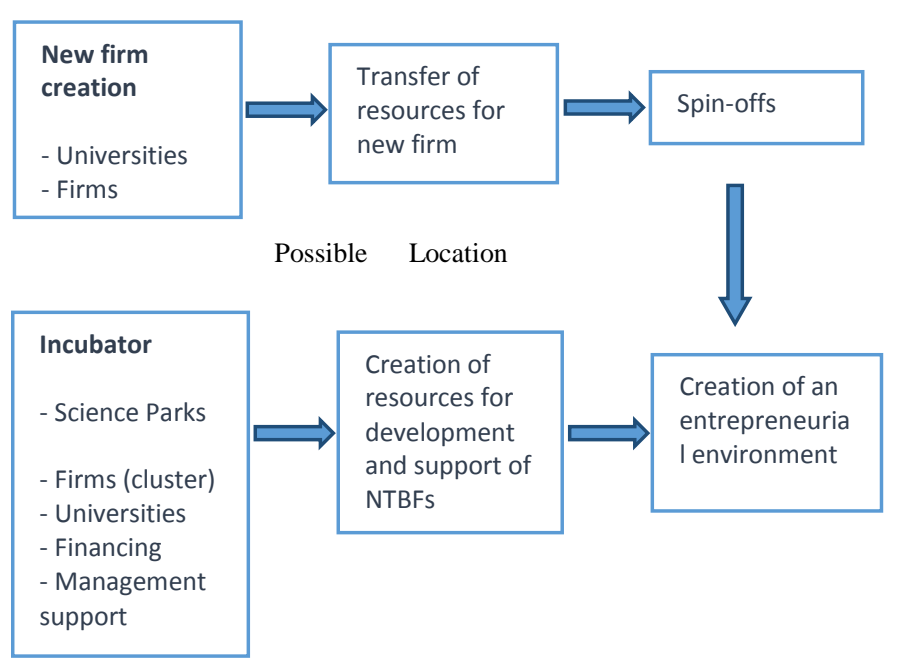

Fig. 2. STPs and the creation of an entrepreneurial environment

Universities and other higher education institutions are an important source of new scientific knowledge. Industry can gain access to this knowledge or resources by developing formal and informal links with higher education institutes[18]. Therefore, the development of higher education institute links is assumed to encourage technology innovation and production[19]. Hence locales with highly interlinked higher education institutes are expected to have enhanced levels of wealth creation and job generation [20].

\subsection{Incubators}

The framework of technology incubators in the science parks have been identified and incorporated in the assessment framework: advantages from pooling resources, sharing resources, consulting services, positive effect from higher public image, networking advantages, clustering effect, geographic proximity, cost subsidies and funding support.

The benefits required by technology founders at different stages of development are varied and therefore, the general merits that are claimed by incubators as useful to technology start-ups are debatable. To meet the needs of technology firms during their stages of development, it is recommended that incubators' services and support should be prioritized in accordance with the development process of the technology firms. It's seen the companies being incubated within the science and technology parks in the world (Fig. 3).

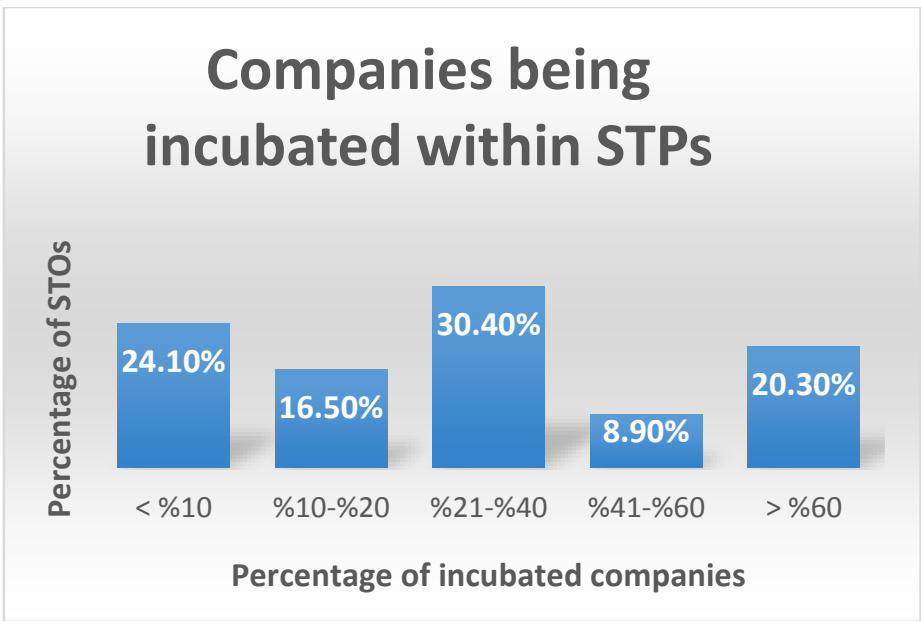

Figure 3. Companies being incubated within STPs

Incubation is important: in $30.4 \%$ of STPs incubates represent between $21 \%$ and $40 \%$ of resident companies.

One of the objectives of establishing the science park in most countries is to provide an infrastructure of technical, logistic and administrative support that a young firm needs in the process of struggling to gain a foothold in a competitive market [21]. It is particularly important to those industrialized economies whereby small high tech firms are encouraged in their start up stage. Therefore, most science parks would accommodate incubator programs leading to the development of technology based firms. It is also widely believed that business incubator can provide a nurturing environment for new business start-up and therefore, leading to later development of growthoriented firms [22].

The role of science parks is to provide the "catalytic incubator environment' needed to transform basic science at universities into commercially viable innovations [14]. The different definitions of science parks concur that the property dimension is a key factor. According to the UK Science Park Association's definition a science park is a property-based activity configured around the following[6]:

$\dagger$ formal operational links with a university or other higher educational or research institution,

$\uparrow$ the formation and growth of knowledge-based business and other organizations normally resident on site, 
$\dagger$ a management function which is actively engaged in the transfer of technology and business skills to the organizations on site.

\section{Conclusions}

The structure and location of the science and technology parks are playing important role on their growth and on regional development economical expectations etc. The collaboration of science and technology parksto university, industry and other stakeholders can effect to achievement of STPs. The spin off companies, new technologies and ideas from incubation centers, and academic supports to the industries, and also academician firms and collaboration them to angel investors'cause to create and improve to the new generation science and technology parks.

The existing university research centers should switch themselves to the new generation STPs to be successful and provide the expectations from them.

While creation of a new STP, it should be analyzed to all regional opportunities and difficulties. After that, the

\section{References}

[1].http://www.unesco.org/new/en/naturalsciences/science-technology/university-industrypartnerships/

[2] http://odtuteknokent.com.tr/

[3] http://www.iasp.ws/statistics

[4] Autio, E., Klofsten, M. "A comparative study of two European business incubators". Journal of Small Business Management 36(1), 30-43, 1998.

[5] Nowotny et al. "Re-thinking science: knowledge and the public in an age of uncertainty". Polity Press, Cambridge, 2001.

[6] K.F. Chan, Lau, T. "Assessing technology incubator programs in the science park: the good, the bad and the ugly". Technovation 25, 1215-1228, 2005.

[7] Storey, D.J., Tether, B.S. "Public policy measures to support new technology-based firms in the European Union”. Research Policy, 26, 1037-1057, 1998.

[13] Westhead, P. "R\&D inputs and outputs of technologybased firms located on and off Science Parks". $R \& D$ Management, 27(1), 45-62, 1997.

[14] Deeds, D., Decarolis, D.L., Coombs, J.E. "The determinants of research productivity in high technology ventures: an empirical analysis of new biotechnology structure can be designed based on local advantages which can effect to their specialization. It can be created and specialists science park or generalist science park depend on the expectations and regional advantages.

For creation and actuation a STP, the necessitiesar[23];

Stake holders; regional and national governmental organizations, universities and institutions, industry and business sector collaborations, which they should apperceive the role of STPs, have well network each other.

Clusters; based on regional and industrial advantages.

Specialization; based on regional advantages.

Academicians and researchers; human source to create new technology and ideas.

Close relation to universities and institutes; for supervising, source of the staff and laboratories.

[8] Quintas, P., Wield, D., Massey, D. "Academic-industry links and innovation: questioning the science park model". Technovation, 12(3), 161-175, 1992.

[9] Monck, C.S.P., Porter, R.B., Quintas, P., Storey, D.J., Wynarczyk, P. "Science Parks and the Growth of High Technology Firms”, Croom Helm, London, 1988.

[10] Johannisson, B. "Personal networks in emerging knowledge-based firms: spatial and functional patterns". Entrepreneurship and Regional Development, 10, 297312, 1998.

[11] Sahlin-Andersson, K. "Forskningsparker och företagsrelationer: Etablering av Novum forskningspark i organisationsteoretisk belysning (in Swedish)". Regionplane - och trafikkontoret, Stockholm, 1990.

[12] Löwegren-Williams, M. "Advantages of a science park location: case studies from the Ideon science park". University of Lund, 2000.

firms". Journal of Business Venturing 15(2), 211-229, 2000 .

[15] Lane, P., Lubatkin, M. "Relative absorptive capacity and interorganizational learning". Strategic Management Journal, 9, 461-477, 1998. 
[16] Pouder, R., St John, R. "Hot spots and blind spots: geographical clusters of firms and innovation". Academy of Management Review, 21, 1192-1225, 1996.

[17] Löfsten, H., Lindelöf, H. "R\&D networks and product innovation patterns - academic and non-academic new technology-based firms on Science Parks". Technovation, 25, 1025-1037, 2005.

[18] OECD. "Small and Medium-sized Enterprises: Technology and Competitiveness". Economic CoOperation and Development, Paris, 1993.

[19] Westhead, P., Storey, D.J. “An Assessment of Firms Located On and Off Science Parks in the United Kingdom". HMSO, London, 1994.
[20] Malecki, E.J. "Technology and Economic Development: the Dynamics of Local, Regional and National Change". Longman, London, 1991.

[21] Guy, I. "A look at Aston Science Park". Technovation, 16, 217-218, 1996.

[22] Cooper, A.C. "The role of incubator organizations in the founding of growth-oriented firms". Journal of Business Venturing, 1, 75-86, 1985.

[23] Gursel, A. "Düzce Teknopark; Stratejik Yol Haritas1 Çalıştayı". Düzce Teknopark Çalıştay Raporu, Düzce, 2012. 